\title{
Rola „Przeglądu Pedagogicznego” (1882-1905) w upowszechnianiu czytelnictwa i książki dziecięcej
}

Początki polskiej literatury dla dzieci sięgają lat 20. XIX w. i związane są z dwoma nazwiskami - Klementyny z Tańskich Hofmanowej i Stanisława Jachowicza. Mimo że w literaturze ogólnej zaczęły już dominować idee romantyzmu, to jednak twórczość tych dwojga pozostawała pod wpływem zracjonalizowanej ideologii oświeceniowej. Ukształtowana wówczas tendencja traktowania książek dla dzieci jako narzędzia praktyki wychowawczej będzie obowiązywać do końca XIX w.

Normy utylitarystyczne i obowiązek wychowawczego oddziaływania na czytelników w szczególny sposób zaważyły na kształcie literatury dziecięcej po roku 1864 . Od lat 70 . rozwija się ona pod wpływem pozytywistycznego programu wychowawczego, a jak wiadomo, kwestie oświatowe i wychowawcze zyskały wtedy rangę problemów ogólnospołecznych.

Książce dla najmłodszych wyznaczono wówczas rozliczne funkcje. Przede wszystkim miała spełniać rolę poznawczą, popularyzować wiedzę, szczególnie przyrodniczą, uzupełniać luki wynikające z programu szkół rządowych i wspomagać nauczanie domowe. Poprzez odpowiednie wzory osobowe literatura miała także propagować samodzielność, zaradność, kult pracy i użyteczności społecznej. $Z$ biegiem lat coraz większego znaczenia nabierała też funkcja podtrzymywania świadomości narodowej i kształtowania uczuć patriotycznych ${ }^{1}$.

W sytuacji objawiającego się społecznego zapotrzebowania na uczestnictwo literatury w procesie kształcenia i wychowywania młodego pokolenia, wyraźnie poszerza się, w stosunku do okresu wcześniejszego, środowisko twórców

* Dr hab., prof. UŁ, Uniwersytet Łódzki, Wydział Filologiczny, Kierownik Katedry Bibliotekoznawstwa i Informacji Naukowej, 90-237 Łódź, ul. Jana Matejki 34A.

1 Zob. H. Markiewicz, Pozytywizm, Warszawa 1999, s. 338-344; K. Kuliczkowska, Literatura dla dzieci i młodzieży w latach 1864-1918. Zarys monograficzny. Materiały, Warszawa 1981, s. 29-31; G. Skotnicka, Literatura dla dzieci w latach 1864-1918, [w:] Kultura literacka w przedszkolu, cz. 1, red. S. Frycie, I. Kaniowska-Lewańska, Warszawa 1988, s. 34-36. 
i współtwórców książek dla dzieci. Tworzą zaś to środowisko autorzy tekstów (najczęściej nauczycielki traktujące swą pracę literacką jako przedłużenie oddziaływania wychowawczego), ilustratorzy, wydawcy, drukarze, a także w pewnym stopniu publicyści, którzy efekty pracy wyżej wymienionych oceniają i inspirują do dalszych działań.

II połowa XIX w. przyniosła też istotne zmiany w edytorstwie książki dziecięcej. Stopniowo i systematycznie rozwijał się rynek wydawniczy i rosła liczba adresowanych do młodego odbiorcy publikacji, zmieniał się także ich wygląd, a szczególnie warstwa wizualna, projektowana niejednokrotnie przez znanych grafików. Obok odrębnych działów książki dziecięcej w znanych firmach wydawniczych (Gebethner i Wolff) powstają pierwsze oficyny, które specjalizują się w edytorstwie publikacji dla najmłodszych (W. Hoesick, M. Arct). Łącznie, jak wynika z wydanej przed dwoma laty Bibliografii literatury dla dzieci i młodzieży², w wieku XIX opublikowano 4082 książki beletrystyczne dla młodych czytelników, z czego zdecydowaną większość właśnie w II połowie stulecia.

Ukazanie się wspomnianej Bibliografii (aczkolwiek niewykluczone, że podobnie jak większość bibliografii retrospektywnych nie jest ona kompletna) z jednej strony potwierdza zasadność prowadzenia badań nad polską książką dziecięcą w przeszłości, a z drugiej dalsze prowadzenie tych badań ułatwia, tym bardziej że książka dla dziecka staje się coraz częściej interdyscyplinarnym obiektem badawczym. Dziewiętnastowieczne wydawnictwa dziecięce są obecnie przedmiotem zainteresowania nie tylko literaturoznawców, bibliologów, historyków sztuki, ale także przedstawicieli nowej dyscypliny - historii dzieciństwa ${ }^{3}$.

Istotną częścią badań nad społecznym obiegiem książek dla dzieci w XIX w. jest także zagadnienie ich popularyzacji, szczególnie za pomocą intensywnie rozwijającej się w II połowie stulecia prasy. Dotychczasowe kwerendy pokazują, że większość ówczesnych czasopism społeczno-kulturalnych, takich jak: „Biblioteka Warszawska”, „Bluszcz”, „Tygodnik Ilustrowany”, „Ateneum”, „Przegląd Tygodniowy”, „Opiekun Domowy”, „Niwa”, mniej lub bardziej systematycznie zamieszczała recenzje i/lub zestawienia bibliograficzne książek dla dzieci. Autorami tych opracowań byli zazwyczaj krytycy profesjonalni, ale również parający się działalnością krytyczną nauczyciele oraz działacze oświatowi i społeczni. Wiele recenzji wychodziło też spod pióra samych twórców literatury, także tej dla dorosłych czytelników4.

Istotne (aczkolwiek krótkotrwałe) dla procesu upowszechniania książki dziecięcej okazały się działania redagowanego przez S. Dicksteina, a publikowanego

2 E. Boczar, Bibliografia literatury dla dzieci i młodzieży. Wiek XIX. Literatura polska i przekłady, Warszawa 2010, s. 571.

3 Więcej na temat badań nad dziewiętnastowieczną książką dziecięcą zob. w: R. Waksmund, Krytyka literatury dla dzieci i młodzieży na łamach „Biblioteki Warszawskiej”, [w:] Literatura i wyobraźnia. Prace ofiarowane Profesorowi T. Żabskiemu w 70. rocznice urodzin, red. J. Kolbuszewski, Wrocław 2006, s. 577-586; J. Konieczna, Dziewiętnastowieczna książka dziecięca. Dokonania i perspektywy badawcze, [w:] Bibliologia i informatologia, red. D. Kuźmina, Warszawa 2011, s. 101-109.

${ }_{4}^{4}$ Zob. G. Skotnicka, Pozytywistyczne powieści z dziejów narodu dla dzieci i młodzieży, Gdańsk 1974, s. 20-44. 
w latach 1882-1883 nakładem Gebethnera i Wolffa, wydawnictwa pt. „Rocznik Pedagogiczny". W tomie I, za rok 1881, omówiono 15 pozycji (książki i czasopisma) adresowanych do młodego odbiorcy, a w dziale „Bibliografia”, w grupie IV zatytułowanej „Książki dla dzieci i młodzieży” znalazły się opisy 64 książek opublikowanych przez różnych wydawców. Ponadto w tomie tym zamieszczony został „Katalog książek dla dzieci i młodzieży wydanych nakładem Gebethnera i Wolffa” oraz wykaz „Najnowsze książki i nuty nakładem F. Hoesicka”.

Najwięcej miejsca sprawie popularyzacji książek dla dzieci poświęciło jednak pierwsze w Królestwie czasopismo poświęcone „sprawom wychowania szkolnego i domowego”, czyli „Przegląd Pedagogiczny”. Ukazujący się w latach 18821905 periodyk był już niejednokrotnie przedmiotem badań naukowych, doczekał się także swojej monografii ${ }^{6}$, jednak wśród rozlicznych zasług, jakie położył dla rozwoju teorii i praktyki pedagogicznej, nie uwzględniono, jak dotychczas, roli czasopisma w zakresie upowszechniania książki i czytelnictwa dzieci i młodzieży.

Celem niniejszego opracowania będzie przedstawienie stopnia intensywności działań popularyzatorskich pisma w tym zakresie, analiza i omówienie stosowanych form przekazu, ich treści, wskazanie uwarunkowań wewnętrznych (redaktorzy, wydawcy, autorzy tekstów) i zewnętrznych (sytuacja społeczno-polityczna, rynek wydawniczy książki dziecięcej) tych działań oraz, w miarę możliwości, porównanie z innymi współczesnymi czasopismami.

Łącznie, na przestrzeni 24 lat ukazywania się „Przeglądu Pedagogicznego" na jego łamach ukazało się ponad 350 tekstów poświęconych, w całości lub częściowo, książkom i czytelnictwu dzieci i młodzieży. Liczba ta obejmuje jedynie materiały przygotowane przez redakcję czasopisma, natomiast podobnie jak w innych periodykach, w „Przeglądzie” znaleźć można było także materiały pozaredakcyjne, czyli kilkadziesiąt ogłoszeń i anonsów reklamujących książki i czasopisma dla dzieci.

Wśród materiałów odredakcyjnych zdecydowanie przeważają (blisko 300 pozycji) teksty o charakterze krytycznym oceniające i rekomendujące (lub nie) wybrane książki dla dzieci, publikowane bądź w określonych zestawieniach (np. wydawnictwa gwiazdkowe), bądź też jako odrębne opracowania. Nieliczne były natomiast wykazy wydawnictw dziecięcych zawierające tylko opisy bibliograficzne.

Pozostałe materiały odredakcyjne to m.in. różnego rodzaju rozprawki podejmujące problem czytelnictwa dzieci i młodzieży, łącznie ze szczegółowym

5 „Rocznik Pedagogiczny” wydawany staraniem i pod redakcją S. Dicksteina przy współudziale wielu pedagogów, Rok I (1881). Obszerna recenzja „Rocznika” znalazła się w „Ateneum” 1882, t. 1, s. 560-566.

6 Są to m.in.: „Przegląd Pedagogiczny” 1882-1905. Dzieje wydawnictwa oraz spis rzeczy i autorów, oprac. A. Białowiejski, A. Jaczynowski, E. Konopczyński i in., Warszawa 1907; Z. Kmiecik, Z dziejów „Przeglądu Pedagogicznego” (1882-1905). Rozprawy z Dziejów Oświaty, Wrocław 1971, t. XIV; W. J. Dyner, Wpływ „Przeglądu Pedagogicznego” na rozwój idei pedagogicznej w Polsce w latach 1882-1905, „Rocznik Komisji Nauk Pedagogicznych”, Wrocław 1975, t. XX; T. Kamiński, Przegląd Pedagogiczny (1882-1905). Zarys monograficzny, Wrocław 1978.

7 Wszystkich prezentowanych w pracy obliczeń dokonano na podstawie zbiorczego spisu treści znajdującego się w książce „Przegląd Pedagogiczny” 1882-1905. Dzieje wydawnictwa..., s. 3-129 oraz na podstawie kwerendy poszczególnych zachowanych roczników. 
omówieniem wyników (pierwszych chyba) badań zainteresowań czytelniczych tej grupy odbiorców. Ukazało się też kilkanaście prac poświęconych znanym ówczesnym twórcom literatury dla dzieci oraz nieliczne opracowania o charakterze teoretycznym dotyczące relacji dziecko-książka.

Częstotliwość i liczba publikowanych tekstów o charakterze krytycznym zmieniała się na przestrzeni 24 lat. Przyczyn tej różnorodności można upatrywać w kolejnych zmianach redaktorów naczelnych i składu komitetu redakcyjnego, ale także w wielkości aktualnej oferty wydawniczej publikacji dla najmłodszych. Natomiast wartość merytoryczna poszczególnych tekstów zależała głównie od poziomu kompetencji ich autorów, chociaż z czasem stawała się też odzwierciedleniem przemian zachodzących na styku dziecko-literatura-pedagogika.

Omówienia krytyczne nowości wydawniczych znalazły się już w pierwszym roczniku „Przeglądu”, czyli w roku 1882. Były to jednak wyłącznie recenzje podręczników i publikacji pedagogicznych. Dopiero w następnym roku, w pierwszym numerze, ukażą się cztery recenzje pozycji beletrystycznych dla młodzieży i będą to jedyne w tym roku formy popularyzacji książki dla młodych. Ten widoczny brak zainteresowania wydawnictwami dla dzieci wynikał najprawdopodobniej z pewnego, jak to nazwał T. Kamiński, autor monografii „Przeglądu Pedagogicznego”, „braku klarowności w programie pisma, w pierwszych latach istnienia, [...] z jego zbyt ogólnego charakteru"8. Trzeba też zauważyć, że oferta wydawnictw dla dzieci była jeszcze na przełomie lat 70 . i 80 . stosunkowo skromna. Wprawdzie księgarnia Gebethnera i Wolffa pierwszą książkę dla dzieci wydała już w roku 1861, to jednak jej roczna „produkcja” wahała się wówczas od 2 do 11 tytułów i miała wyraźnie wzrosnąć dopiero u progu lat $90^{9}$. Również skromnie prezentowała się oferta oficyny W. Hoesicka, jedynej wówczas firmy, która od roku 1868 specjalizowała się (obok wydawnictw nutowych) w publikowaniu książek dla dzieci'10.

Niewykluczone, że ograniczone zainteresowanie „Przeglądu” popularyzowaniem książek dla dzieci wynikało też z faktu, iż - jak pisał w 1882 r. Piotr Chmielowski, dokonując w „Ateneum” cyklicznego przeglądu książek dla dzieci - „Przez czas bardzo długi sprawozdawca z ruchu pedagogicznego utyskiwać musiał na brak utworów oryginalnych w zakresie beletrystyki dla młodzieży. Jeszcze przed czterema laty, oprócz przedruków dziełek dawniejszych, nie było prawie wcale rzeczy swojskich; wydawcy ogłaszali same przekłady, które naturalnie i łatwiej i taniej dostawali. [...] Zdaje się, że powoli zaczynamy z tego smutnego stanu się dźwigać"11.

8 T. Kamiński, „Przegląd Pedagogiczny”..., s. 26.

9 Do roku 1905 Gebethner i Wolff opublikowali ponad 400 tytułów książek dla dzieci i młodzieży - zob. J. Muszkowski, Z dziejów firmy Gebethner i Wolff 1857-1937, Warszawa 1938, s. 45-49, tabl. 2.

10 Do roku 1900 Hoesick wydał ok. 90 pozycji dla młodych czytelników, co stanowiło ok. $30 \%$ całej jego produkcji wydawniczej. W roku 1900 firmę przejął syn i kontynuował działalność do roku 1905, wydając jeszcze kilkanaście pozycji - zob. E. Boczar, Dziewiętnastowieczny wydawca książek dla dzieci i młodzieży - Ferdynand Hoesick, [w:] Z zagadnień literatury dziecięcej (Studia i materiały), zeszyt naukowy „Guliwera”, Warszawa 1995, s. 31-35; Słownik pracowników książki polskiej, Warszawa 1972, s. 333-334.

11 P. Chmielowski, Książki dla młodzieży, „Ateneum” 1882, t. 1, s. 167-177. 
Zwyczaj informowania na łamach „Przeglądu” o nowościach z zakresu literatury dziecięcej i młodzieżowej zaczyna się utrwalać poczynając od roku 1884, kiedy to ukazał się pierwszy obszerny spis książek dla dzieci autorstwa Władysława Nowickiego, polonisty w Instytucie Głuchoniemych i Ociemniałych w Warszawie, zatytułowany Gwiazdka dla naszej dziatwy. Podobny zestaw, pt. Belletrystyka dla małych dzieci, tego samego autora, ukazał się również w roku następnym ${ }^{12}$. W tym samym, 1885 r., „Przegląd” zaczął publikować odrębne omówienia dotyczące zawartości treściowej czasopism dla dzieci (czyli „Przyjaciela Dzieci” i/lub „Wieczorów Rodzinnych") w poprzednim roku kalendarzowym. Prezentacji i oceny dokonywali w latach 1885-1889 znani ówcześni pisarze dla dzieci - Zofia Urbanowska i Stefan Gębarski, a w latach 1890 i 1891 - Aniela Szycówna. Recenzenci najwięcej uwagi poświęcali zazwyczaj ocenie treści literackich prezentowanych na łamach danego periodyku, chociaż uwzględniali także istniejące tam działy popularnonaukowe. Po dłuższej przerwie temat czasopism dla dzieci powrócił w roku 1903, kiedy to obszernie ( $w$ trzech numerach) omówiła je Iza Moszczeńska. Przedmiotem analizy, obok dwóch wspomnianych wcześniej periodyków, stał się również zainicjowany w 1902 r. przez A. Szycównę tygodnik „Moje Pisemko”. Omawiając zawartość literacką nowego, adresowanego do najmłodszych czytelników czasopisma, recenzentka przy okazji zauważyła, że brakuje u nas dobrej literatury dla najmłodszych, gdyż, jak podkreśliła, „[...] była ona zawsze u nas po macoszemu traktowana w myśl zupełnie fałszywej zasady, że im dziecko mniejsze, tem lichszemi rzeczami zadawalniać się powinno zarówno w nauce jak i w rozrywce"13. Zakończyła zaś swą wypowiedź gorzką, ale znamienną dla czasu, w którym powstała, refleksją: „We Lwowie mówi się już dziś o sztuce dla dzieci, u nas o tem wciąż jeszcze głucho"14.

Przełom lat 80. i 90. przynosi wyraźne poszerzenie form i liczby informacji o książkach dla dzieci i młodzieży na łamach „Przeglądu Pedagogicznego”. Wynikało to zapewne, z jednej strony, $z$ faktu szybkiego powiększania się oferty wydawnictw dla młodych czytelników, wskutek rozpoczęcia, w 1887 r., działalności nakładowej przez Michała Arcta ${ }^{15}$, do którego dołączyli wkrótce z mniejszą, ale wartościową ofertą G. Centnerszwer, T. Paprocki i K. Trepte ${ }^{16}$, z drugiej zaś związane było z objęciem w 1890 r. stanowiska redaktora „Przeglądu Pedagogicznego”

12 Przygotowywane dla „Przeglądu Pedagogicznego” wykazy książek dla dzieci posłużyły W. Nowickiemu do opracowania i wydania w roku 1886 katalogu zatytułowanego Co dać dziecku na gwiazdkę?

13 I. Moszczeńska, Czasopisma dla dzieci, „Przegląd Pedagogiczny” 1903, nr 11, s. 140.

14 Tamże.

15 M. Arct w roku 1887 przeniósł do Warszawy prowadzoną dotychczas w Lublinie księgarnię i szybko stał się liderem na rynku wydawców książek dziecięcych. Do roku 1914, czyli w ciągu 27 lat, opublikował 718 pozycji dla młodych czytelników, podczas gdy Gebethner i Wolff w latach 18611914 wydali 608 pozycji - zob. S. Arct, E. Pawłowska, Wydawcy warszawscy w latach 1878-1914, [w:] Z dziejów książki i bibliotek w Warszawie, Warszawa 1961, s. 356-357.

16 Zob. J. Konieczna, Rynek wydawniczy książki dziecięcej w zaborze rosyjskim w XIX $i$ w początkach XX wieku, referat wygłoszony na konferencji pt. „Dziewiętnastowieczne edycje - dziewiętnastowieczni edytorzy", zorganizowanej przez Uniwersytet Mikołaja Kopernika w Toruniu, w dniu 6.10.2010 r. i przyjęty do druku w materiałach pokonferencyjnych tamże. 
przez najwybitniejszego wówczas w Królestwie Polskim pedagoga i psychologa - Jana Władysława Dawida. Poglądy nowego redaktora na książkę i lektury dzieci i młodzieży ukształtowane w wyniku prowadzonych przezeń badań rozwoju umysłowego i zainteresowań najmłodszych oraz pozyskanie do współpracy osób zainteresowanych literaturą dla dzieci i rolą sztuki w życiu dziecka w osobach Anny Szycówny, Stanisława Karpowicza i Izy Moszczeńskiej sprawiły, że dotychczasowe formy popularyzacji nowości wydawniczych i czytelnictwa dzieci stopniowo ulegały zmianie. Ten nowy kierunek w ocenie i prezentacji książek dla dzieci będzie widoczny nadal, również i po odejściu J. W. Dawida w 1898 r. ze stanowiska redaktora i ograniczeniu współpracy przez A. Szycównę, jest to już bowiem okres wyraźnych zmian w samej literaturze dziecięcej, a także na rynku wydawniczym tego typu publikacji.

Prowadzona na łamach „Przeglądu” działalność krytycznoliteracka dotycząca książki dziecięcej adresowana była zawsze do pedagogów i rodziców/opiekunów, a realizowana w dwóch zasadniczych formach - krótkich adnotacji treściowych lub dłuższych omówień o charakterze recenzji. Przeważały pierwsze formy (stosowane szczególnie w przeglądach gwiazdkowych), budowane według określonego schematu. Podawano więc dane formalno-wydawnicze książki, łącznie z ceną i typem oprawy, dalej następowało krótkie streszczenie i określenie pedagogicznej wartości (lub jej braku) publikacji, kończono zaś rekomendacją i wskazaniem grupy czytelników (najczęściej z podaniem przedziału wiekowego), dla których jest ona odpowiednia. W trosce o rozwój poprawnej polszczyzny wskazywano też błędy językowe i oceniano warstwę wizualną publikacji. W praktyce rekomendacje wyglądały mniej więcej tak: „O całym zbiorku powiedzieć należy, że dostarczy on sporo zdrowej strawy i potrafi zająć młodą główkę. Jako przeznaczona dla małych dzieci książeczka drukowana jest dużemi czcionkami”" lub też: „Myśl utworu jest zacna i szlachetna, ton podniosły, a postaci dodatnie: matki i panny Jadwigi, skreślone sympatycznie i naturalnie, mogą obudzić w młodych czytelniczkach chęć wstępowania w ich ślady"18. Wprawdzie nieczęsto, ale zdarzały się także opinie negatywne i brak rekomendacji, jak w przypadku wydanej w 1892 roku przez wydawnictwo Orgelbranda Wiązanki dla dzieci. Podpisana pseudonimem (nierozwiązanym) W. siostra książeczka została tak oceniona przez Z. Morawską: „Jeżeli jest zadaniem naszem zachęcać do czytania pożytecznych i pouczających książek powinno być obowiązkiem ostrzegać o szkodliwych pod każdym względem. Taką jest powyżej wymieniona"19.

Teksty omówień podpisywane były zazwyczaj inicjałami imienia i nazwiska, chociaż zdarzały się też anonimowe. Oceniający wywodzili się przede wszystkim z grona członków komitetu redakcyjnego (Władysław Nowicki, Florian Łagowski, Waldemar Osterloff, Kazimierz Król), ale byli w tej grupie także autorzy książek

17 Opinia dotyczyła książki Marii Weryho pt. Wśród swoich wydanej w Petersburgu w 1903 r., „Przegląd Pedagogiczny” 1902, nr 24, s. 295.

18 Ta wypowiedź odnosiła się do książki M. Raczyńskiej pt. Dzienniczek Hanusi Tynieckiej - „Przegląd Pedagogiczny” 1902, nr 22, s. 267.

19 „Przegląd Pedagogiczny” 1892, nr 13, s. 151. 
dla dzieci (Stefan Gębarski, Zofia Urbanowska, Jadwiga Chrząszczewska, Cecylia Niewiadomska, Zuzanna Morawska). Szczególną jednak rolę w tym obszarze krytyki literackiej odegrały Aniela Szycówna i Iza Moszczeńska.

Ich omówienia i recenzje wyraźnie wykraczały poza niektóre zdawkowe i schematyczne opinie o publikacjach dla dzieci. Oprócz tradycyjnego streszczenia i wykazania, zazwyczaj w niebanalny sposób, wartości pedagogicznych, można w nich znaleźć ciekawe uwagi na temat literatury i czytelnictwa dzieci i młodzieży. Coraz bardziej widoczna staje się w początkach wieku, w ich wystąpieniach na łamach „Przeglądu”, reakcja przeciw pozytywizmowi, obecnemu zarówno w dziedzinie wychowania, jak i ciągle jeszcze $w$ literaturze dla dzieci. Obydwie autorki dostrzegają niedostatki literatury dla młodych czytelników, zwłaszcza tzw. powieści obyczajowej, i oceniają krytycznie dominujący w niej nadal dydaktyzm i wąsko pojmowany praktycyzm. Oto np. omawiając wydaną w 1903 r. typową powieść „z tezą", zatytułowaną Dług ojcowski, dość popularnej wówczas autorki Eugenii Leśniewskiej (piszącej pod pseudonimem Jerlicz), I. Moszczeńska, nie odmawiając książce pewnych wartości, zadała jednak pytanie: „Inna rzecz, czy tendencyjność ma być zawsze uważana za konieczną w książkach dla młodzieży, lub czy ją się w ogóle uważa za cechę dodatnią. Możnaby żądać od autorów takich książeczek trochę więcej artyzmu, pomysłowości, bogactwa typów, żywości akcji, trochę - choćby troszeczkę - tak rzadkiego a tak pożądanego w powieściach dla dzieci i młodzieży humoru; jednakże takie żądanie czy taki zarzut należałoby skierować do wszystkich niemal bez wyjątku autorów i do wszystkich niemal książeczek tego typu"20.

Niezależnie od licznych uwag krytycznych pod adresem bieżącej produkcji wydawniczej, zarówno Moszczeńska jak i Szycówna dostrzegają jednak symptomy rodzących się w literaturze dla dzieci nowych tendencji i w swoich ocenach zdecydowanie to podkreślają. I tak I. Moszczeńska, pisząc o książce A. Domańskiej Przyjaciółki, zauważa np.: „Dzieci w książeczkach pani Domańskiej nie dzielą się na grzeczne i niegrzeczne, jak w wielu innych, których zadaniem zdaje się być przedstawienie kilku wzorów do naśladowania i kilku innych odstraszających"21. Z podobnym uznaniem wyrażała się też o wydanej w 1900 r. powieści Zofii Bukowieckiej pt. Jak się dusza budziła w Józiu, powieści, która wprawdzie nie była zupełnie wolna od dydaktyzmu, ale prezentowała już sylwetkę bohatera kształtującego swą osobowość poprzez stosunek do bliźnich ${ }^{22}$.

Z kolei A. Szycówna, w obszernym opracowaniu zatytułowanym Maria Konopnicka, jako autorka dla dzieci, po dokonaniu wnikliwej analizy wybranych utworów poetki i niezwykle wysokiej ocenie jej twórczości, sformułowała inne, niż czynili to pozytywiści, wymagania pod adresem literatury dla dzieci. Jej zdaniem „[...] pedagog piszący dla dzieci musi być zarazem artystą. Ażeby bowiem utwór jakiś literacki wywarł wpływ istotny, musi on nie tylko odpowiadać warunkom pedagogicznym, lecz też być dziełem istotnego talentu". Bowiem, zdaniem autorki

20 Tamże 1903, nr 23, s. 282.
21 Tamże 1903, nr 24, s. 294.
22 Tamże 1900, nr 24, s. 283. 
opracowania „[...] książka dla dziecka ma stokroć większe znaczenie, niż dla dorosłego”23. Dlatego Szycówna postuluje, aby „prawdziwi poeci”, tak jak Konopnicka, dostrzegali w społeczeństwie również dzieci i poświęcali im swoje utwory. Oprócz warstwy teoretycznej w artykule znalazły się też szczegółowe informacje o wszystkich opublikowanych dotychczas (w zdecydowanej większości przez Arcta) tomikach Konopnickiej dla dzieci.

Nie tylko jednak proza obyczajowa (najczęściej) i utwory poetyckie (rzadziej) były przedmiotem omówienia i rekomendacji na łamach „Przeglądu”. Wprawdzie wielkość zamieszczanej na łamach czasopisma oferty książkowej była w dużym stopniu odzwierciedleniem sytuacji panującej na rynku wydawniczym, to jednak w kwestii doboru konkretnych pozycji czy preferowania określonych gatunków literackich redakcja zazwyczaj prezentowała własne stanowisko.

Realizując pozytywistyczne hasła kultu wiedzy, zwłaszcza przyrodniczej, dużo uwagi poświęcano wszelkim beletryzacjom popularnonaukowym, lub później, powieściom fantastyczno-przyrodniczym. Szczególnie w okresie, gdy redakcją kierował J. W. Dawid, gorący zwolennik „nauki o rzeczach”, omówiono kilkadziesiąt tego typu publikacji. Najczęściej polecani autorzy to znani popularyzatorzy: M. Brzeziński, M. J. Zaleska, J. Chrząszczewska, M. Weryho, J. Warnkówna, B. Dyakowski, ale także pisarka Z. Urbanowska. Zdarzały się również oceny krytyczne, jak w przypadku książki pt. Nowe wieczory czwartkowe, znanej chemiczki Zofii Joteyko-Rudnickiej. Recenzentka zarzuciła książce przeładowanie treściami naukowymi przy jednoczesnym braku umiejętności jasnego i interesującego ich przekazu²4.

Względy poznawcze w połączeniu z oddziaływaniem wychowawczym, zwłaszcza w zakresie budzenia i kształtowania uczuć patriotycznych, stanowiły główne kryterium oceny powieści historycznych. Publikowane w „Przeglądzie" liczne omówienia i recenzje są potwierdzeniem ewolucji, jaka dokonała się w II połowie stulecia w poglądach na rolę i sens istnienia powieści historycznych dla młodego pokolenia. Rosnąca bowiem od drugiej połowy lat 80. obfitość utworów historycznych dowodziła, że utylitarne koncepcje pedagogiczne, w których nie przewidywano miejsca na wychowanie w duchu kultu historii i tradycji, odchodziły już do przeszłości ${ }^{25}$. W przeciągu niespełna 20 lat na łamach „Przeglądu” poddano ocenie wszystkie niemal powieści historyczne Jadwigi Papi (ponad 20), a także większość powieści W. Przyborowskiego, Z. Morawskiej, E. Sedlaczka (piszącego pod pseudonimem E. Zorjan) i W. Trąmpczyńskiego. W omówieniach

23 Tamże 1902, nr 18, s. 219. Poglądy zaprezentowane w rozprawce o twórczości Konopnickiej rozwinęła następnie Szycówna w pracy zatytułowanej Rys historyczny literatury dziecięcej, zamieszczonej w Encyklopedii wychowawczej (Warszawa 1904) i w tym samym roku opublikowanej w formie odbitki razem z opracowaniem S. Karpowicza pt. Główne cechy i zadania literatury powszechnej dla młodzieży.

24 „Przegląd Pedagogiczny” 1903, nr 1, s. 7-8.

25 Jeszcze w 1882 r., w artykule pt. Ideały naszej młodzieży szkolnej pisał E. Bogdanowicz: „[...] Należy wyrzec się marzeń, romantycznego mierzenia sił na zamiary. Trzeba wdrażać młodzież do zadań realnych dających się urzeczywistnić [...]. Po co uganiać się za celem, który wreszcie złamie nasze skrzydła i w piersi wleje gorycz rozczarowania i truciznę zniechęcenia". Tamże 1882, nr 22, s. 683. 
znaleźć można było nie tylko oceny książek, ścierały się w nich poglądy na funkcję powieści historycznej, a przede wszystkim na rolę i znaczenie postaci historycznych i fikcyjnych ${ }^{26}$.

Stosunkowo obfita produkcja wydawnicza z zakresu prozy przygodowo-podróżniczej była polecana na łamach „Przeglądu”, ale w wyborze. Pedagogowie pozytywistyczni wartość powieści przygodowej widzieli głównie w jej warstwie poznawczej i wychowawczej. Doceniali wprawdzie tłumaczenia obcych utworów (o ile prezentowały wspomniane wartości), przede wszystkim jednak polecali książki polskich autorów, gdyż jak czytamy w recenzji będącej zbiorem opowiadań książki S. Gębarskiego pt. Chatka pod lasem „[...] oprócz bowiem zainteresowania, jakie budzą same przez się, obznajamiają dzieci z różnemi okolicami kraju i przekonywają, że piękności i dziwów przyrody nie potrzeba szukać daleko, znajdziemy je na każdym kroku, bylebyśmy je poznać chcieli"27. Wśród anonsowanych książek przygodowo-podróżniczych dominowały więc utwory W. Umińskiego (także dokonywane przez niego przeróbki obcych pozycji) obok wspomnianego S. Gębarskiego i pojedynczych opowieści krajoznawczych J. M. Zaleskiej, W. Gomulickiego, M. Brzezińskiego. Do tłumaczeń obcych tekstów, mimo że ukazywało się ich bardzo dużo i cieszyły się ogromnym zainteresowaniem młodych ludzi, odnoszono się krytycznie i polecano tylko nieliczne ${ }^{28}$.

W przeciwieństwie do warstwy tekstowej warstwa wizualna książek dla dzieci rzadko bywała przedmiotem głębszej analizy recenzentów. Przez wiele lat, $z$ reguły, nie wychodzili oni w swoich wypowiedziach poza zdawkowe oceny ilustracji lub oprawy, nie dostrzegając kryjących się w literaturze oraz jej materializacji w postaci książki potencjalnych możliwości kształcenia dziecięcej wyobraźni i poczucia piękna. Dopiero gdy przełom wieków zapoczątkował odchodzenie od utylitarnej funkcji szkoły, przynosząc intensywny rozwój kierunku zwanego „wychowaniem przez sztukę", te nowe koncepcje znalazły swe miejsce również na łamach „Przeglądu Pedagogicznego”. Problematykę wychowania estetycznego podejmowały w czasopiśmie m.in. W. Marrene-Morzkowska i I. Moszczeńska ${ }^{29}$.

${ }^{26}$ Widać to np. w sąsiadujących ze sobą recenzjach książki J. Papi Dworzanin królewicza Jakuba i powieści W. Przyborowskiego Austriacy w Warszawie. O pierwszej z nich czytamy: „Pomimo więc szkicowego tylko (niekiedy nazbyt szkicowego) rysunku postaci i epizodów, młody czytelnik nabierze zgodnego z prawdą pojęcia o rzeczach [czyli historii]; ta zaś okoliczność pozwala nam zapomnieć o niektórych brakach artystycznych obrazowania”. Zaś w przypadku drugiej, opisującej głównie przygody niejakiego Stacha Kalafiora w czasach Księstwa Warszawskiego, napisano: „Co daje powieść taka? Historii - nie. Prawdy - nie. Typów ludzkich - nie”, tamże 1902, nr 24, s. 295.

27 Tamże 1894, nr 24, s. 307.

${ }_{28}$ Tak np. A. Szycówna pisała o książce R. L. Stevensona wydanej w 1893 r. pt. Skarby na wyspie (później znanej jako Wyspa skarbów): „Jest to jedna z tych książek, o których można powiedzieć, że powiększyły literaturę dziecinną, lecz jej nie wzbogaciły. [...] Pouczającego nic w nich nie ma, treść bowiem książki stanowi wyprawa na nieistniejącą wyspę. [...] Etyczna strona gorzej się jeszcze przedstawia [...]". Tamże 1892, nr 24, s. 316.

${ }_{29}$ Były to m.in. prace: W. Marrene-Morzkowska, Niektóre braki naszego wykształcenia. Wykształcenie estetyczne, „Przegląd Pedagogiczny” 1902, nr 4, s. 49-51; I. Moszczeńska, Rozwój smaku estetycznego u dzieci, „Przegląd Pedagogiczny” 1902, nr 8, s. 86-88; J. Mortkowiczowa, Wychowanie estetyczne, „Przegląd Pedagogiczny” 1904, nr 13, s. 143. 
Natomiast niezwykle ważna dla kwestii wychowania estetycznego najmłodszych, a jednocześnie istotna dla procesu kształtowania nowej roli książki dziecięcej, była zamieszczona na łamach „Przeglądu” w 1904 roku obszerna praca Janiny Mortkowiczowej poświęcona książce obrazkowej dla dzieci. Jako jedna z nielicznych osób podejmujących w czasopiśmie temat wydawnictw dla dzieci, była Mortkowiczowa nie tylko teoretykiem, ale też praktykiem. Pracowała wcześniej w czytelniach Warszawskiego Towarzystwa Dobroczynności, a od 1903 r. prowadziła wspólnie z mężem, Jakubem Mortkowiczem, księgarnię, w której odpowiadała za dział książki dziecięcej. Pod kierunkiem Mortkowiczowej księgarnia wkrótce wyda cały szereg niezwykle starannych edytorsko i wartościowych literacko pozycji dla młodych czytelników, głównie w ramach serii „Dobre Książki dla Młodzieży". Natomiast w roku 1904 opublikowała Mortkowiczowa, opartą na szerokich lekturach zagranicznych (głównie niemieckich), książkę pt. Wychowanie estetyczne. W artykule poświęconym książkom obrazkowym dla dzieci przedstawiła historię kształtowania się tego typu publikacji, ale przede wszystkim starała się wykazać, jak istotną pełnią one rolę w życiu małego człowieka. Zdaniem Mortkowiczowej bowiem „Książka obrazkowa dla dzieci graniczy z jednej strony ze światem zabawek, z drugiej wkracza już w dziedzinę sztuki i literatury. Przypada jej więc rola niezmiernie ważna. Bawi dziecko, zajmuje, sprawia mu żywą przyjemność, daje pokarm jego wiecznie głodnej wyobraźni i stać się może poważnem narzędziem rozwoju umysłowego, estetycznego i moralnego"30. Oceniając krytycznie większość ówczesnej produkcji „obrazkowej” kopiowanej z klisz niemieckich wydawców, wskazała jednocześnie na grupę edycji starannych i wartościowych, zwłaszcza książek Konopnickiej.

Jak wspomniano wcześniej, oprócz licznych adnotowanych form informacji o książkach dla młodych odbiorców, w „Przeglądzie” zamieszczano też wykazy nowości ograniczone jedynie do opisu bibliograficznego anonsowanych publikacji. Pozycje beletrystyczne dla dzieci wymieniane były, często obok książek pedagogicznych, w obrębie takich działów, jak: „Krytyka i sprawozdania”, „Krytyka”, „Wiadomości bibliograficzne” lub też „Książki nadesłane do redakcji”. Tego rodzaju spisy pojawiały się stosunkowo rzadko, zamieszczano je zwykle na końcowych stronach numeru i ze względu na drobny druk nie miały prawdopodobnie dużej siły oddziaływania.

$\mathrm{Na}$ uwagę i szersze omówienie zasługują natomiast dwa bardzo obszerne spisy, które miały charakter cząstkowej bibliografii zalecającej ówczesnego piśmiennictwa dla dzieci. Pierwszy ukazał się w 1892 roku i był uzupełnieniem tradycyjnego, adnotowanego przeglądu gwiazdkowego (18 pozycji). Pod hasłem „Z książek dawniej wydanych polecamy jako najlepsze" zaanonsowano w pięciu grupach, wyodrębnionych na podstawie kryterium wiekowego (do lat 7, 10, 12, 14 i dla starszej młodzieży), ok. 130 pozycji3i. Był to reprezentatywny dla II połowy XIX wieku zestaw literatury dziecięco-młodzieżowej. Znalazły się tu książki auto-

30 J. Mortkowiczowa, O książkach obrazkowych dla dzieci, „Przegląd Pedagogiczny” 1904, nr 21, s. 244-247; nr 22, s. 258-261; nr 23, s. 271-272.

31 Zob. „Przegląd Pedagogiczny” 1892, nr 24, s. 317-318. 
rów polskich (Konopnickiej, Zaleskiej, Kamockiej, Dygasińskiego, Urbanowskiej i innych), ale także i tłumaczenia (Amicisa, Burnett, Campego, Verne'a, Reida), szczególnie w najobszerniejszym dziale „dla dzieci do lat 14”. Obok beletrystyki polecano też książki o charakterze poznawczym (np. E. Muller Młodość sławnych ludzi, A. Carey Z dziedziny przyrody: życiorysy kawałka węgla, ziarnka soli i kropli wody, ułamka zardzewiałego żelaza i bryłki krzemienia) ${ }^{32}$. W przypadku omawianego wykazu opisy ograniczone były jedynie do nazwiska autora, tytułu i ceny.

Drugi ze wspomnianych spisów ukazał się 10 lat później, w roku 1902, w innych już nieco uwarunkowaniach społecznych i pedagogicznych, a także w zmieniającym się z wolna kształcie literatury dla dzieci. Jego autorką była $\mathrm{H}$. Orsza, czyli Helena Radlińska, a wykaz nosił tytuł Na wakacje. Tanie książki dla dzieci i młodzieży (Przegląd krytyczny ok. 150 prawdziwie tanich książek popularnych). Różnił się od podobnych, publikowanych wcześniej, nie tylko mieszaną formą podawczą, gdyż łączył opisy adnotowane z czysto bibliograficznymi, ale także wyraźnym określeniem typu adresata. Jak zadeklarowała bowiem we wstępie autorka, chodziło jej „[...] wyłącznie o zwrócenie uwagi na tanie książeczki dla dzieci, na które reklama księgarskich edycji gwiazdkowych rzuca cień zapomnienia. [...] Zasługują one na baczną uwagę i rozpatrzenie. Przenikając do najszerszych kół czytelniczych, mogą wpływem swoim przygotować pokolenie, wśród którego nie będzie takiej, jak dziś przepaści różnic duchowych"33. Dobór prezentowanych publikacji pod kątem realizacji funkcji poznawczej i wychowawczej spowodował podział materiału na 5 grup rzeczowych: I - Nauka początkowa, II - Książki popularnonaukowe, III - Historia (uwzględniono tu również niektóre powieści historyczne), IV - Poezja. Życiorysy. Dzieje literatury, V - Literatura powieściowa. W obrębie tej ostatniej grupy dodatkowo zastosowano podział na: „powiastki dla małych dzieci, powieści na tle naukowym i powieści społeczne". Zarówno dobór tytułów, jak i opinie towarzyszące niektórym opisom wskazują, że Radlińska postrzegała książkę dla młodego czytelnika przede wszystkim jako źródło wiedzy, nie była bowiem, jak wynika z przedstawionego podziału, zwolenniczką „karmienia dzieci specjalnym piśmiennictwem dla młodocianego wieku"34. Ponieważ, jej zdaniem, młodzi ludzie powinni obcować z literaturą wysoce artystyczną, dopuszczała możliwość korzystania ze streszczeń lub wydań skróconych, a w zaproponowanym przez nią wykazie znalazło się wiele takich pozycji.

Inną formą przekazywania wiedzy o książkach „pożytecznych” były artykuły poświęcone znanym twórcom literatury dla dzieci i młodzieży, publikowane bądź to z okazji jubileuszy, bądź w ramach wspomnień pośmiertnych. Prezentowano w nich dorobek literacki danego autora i jednocześnie podawano szczegółowe informacje o wydaniach książkowych. Obok wspomnianej już pracy o M. Konopnickiej ukazały się, również autorstwa A. Szycówny, artykuły poświęcone J. Papi

32 Tamże.

33 Tamże 1902, nr 11, s. 137-141. Wykaz ten był swoistą odpowiedzią na zamieszczony rok wcześniej spis zatytułowany Na wakacje. (Poradnik dla wybierających książki dla młodzieży, zawierający przeszło 100 ocen i tytułów), tamże 1901, nr 12, s. 145.

34 „Przegląd Pedagogiczny” 1902, nr 11, s. 139. 
(1897) i W. Marrene-Morzkowskiej (1903). Z innych opracowań na uwagę zasługuje m.in. obszerne wspomnienie Z. Urbanowskiej o zmarłej w 1889 r. M. J. Zaleskiej oraz opublikowana w 1896 r., z okazji setnej rocznicy urodzin S. Jachowicza, praca W. Osterloffa o dorobku literackim autora Chorego kotka. Z tej samej okazji ukazała się też w 1898 r. praca J. Nitowskiego o Klementynie z Tańskich Hofmanowej. Okolicznościowy charakter takich opracowań ograniczał jednak ewentualny krytycyzm i stąd wymieniane tam książki omawianego autora oceniane były zazwyczaj jako szczególnie wartościowe i godne polecenia młodym czytelnikom.

Ostatnia część artykułu poświęcona zostanie zaznaczonej w tytule roli „Przeglądu Pedagogicznego" w upowszechnianiu czytelnictwa. Kwestie te pojawiały się już w trakcie prezentowania prowadzonej na łamach czasopisma działalności krytycznoliterackiej, tutaj jednak zostaną poddane analizie wypowiedzi stricte czytelnictwu poświęcone.

Opracowania dotyczące czytelnictwa dzieci i młodzieży, autorstwa różnych osób, można znaleźć we wszystkich niemal rocznikach „Przeglądu”. Prześledzenie prezentowanych w nich poglądów pozwala na ukazanie ewolucji, jaka dokonywała się na przełomie XIX i XX wieku w koncepcjach wychowawczych, w tym także w określeniu miejsca książki i czytania w życiu młodego człowieka, w różnych fazach jego rozwoju.

Jedne z pierwszych wypowiedzi na temat funkcji lektury spotkać można w artykule $O$ nauczaniu moralności w nr 7 z 1883 r. Czytamy tam: „Pod lekturą rozumiemy czytanie $z$ dzieckiem zajmujących, kształcących jego umysł i wzbogacających jego wiedzę ustępów, aby je przyzwyczaić do odczuwania przyjemności w czytaniu i do samodzielnego kształcenia się przez lekturę"35. Aby nie było wątpliwości, że czytelnictwo ma wspomagać funkcję kształcącą, wskazane są właściwe lektury. Miały to być utwory Krasickiego, Tańskiej, Skarbka, Chodźki, „a nawet Walter Scotta".

W miarę rozwoju produkcji wydawniczej przeznaczonej dla dzieci i młodzieży na łamach „Przeglądu” coraz częściej dostrzegano konieczność właściwej organizacji procesu czytania i różne, nie tylko kształcące, jego funkcje. I. Moszczeńska w 1893 r. pisała: „Ze względu na to, że coraz większe miejsce książka w życiu dziecka zajmuje, ze względu na wpływ jej potężny, oczy wychowawców pilnie na nią muszą być zwrócone, gdyż ona może stać się silnym sprzymierzeńcem rodziców i nauczycieli, lub też wrogiem, który usiłowania ich nieraz krzyżować będzie" ${ }^{\prime 36}$. W następnych latach problem czytelnictwa będzie jeszcze niejednokrotnie pojawiał się na łamach „Przeglądu”, przy czym szczegółowe kwestie poruszane przez autorów będą podobne. Rodzice, nauczyciele, wychowawcy winni kierować procesem czytelnictwa, kontrolować zarówno dobór lektur, jak i sprawdzać stopień ich przyswojenia. Dzieci powinny czytać pozycje właściwe dla ich poziomu rozwoju umysłowego (a nie wieku). Należy przeciwdziałać czytaniu nadmiernej liczby książek, gdyż zdaniem większości autorów, odbywa się to kosztem zdrowia, ograniczania samodzielności myślowej i możliwości poznawania życia poprzez

\footnotetext{
35 „Przegląd Pedagogiczny” 1883, nr 7, s. 202.

36 I. Moszczeńska, Mali czytelnicy i ich literatura, „Przegląd Pedagogiczny” 1893, nr 1, s. 17.
} 
obserwację i doświadczenie. Za niewłaściwe uważano też czytanie pobieżne, wyłącznie fragmentów dziecko interesujących ${ }^{37}$. Od tych dość podobnych, zalecających nieustanne czuwanie nad lekturami młodych czytelników, głosów odróżnia się jedno z wystąpień I. Moszczeńskiej. W artykule zatytułowanym Nie dla panien postulowała, aby nie zakazywać dziewczętom czytania romansów i innych podobnych książek. Opisane w nich zdrada czy uwiedzenie mogą mieć niekorzystny wpływ na postępowanie młodej osoby, ale najczęściej w sytuacji, kiedy będzie to lektura zabroniona, czytana ukradkiem. Natomiast za niebezpieczną uważa Moszczeńska literaturę tego typu dla dziewcząt pozbawionych zajęć, utwierdzanych przez otoczenie w przekonaniu, że jedynie w miłości i małżeństwie kobieta powinna się realizować38.

W czasach gdy pismem kierował J. W. Dawid, niezależnie od publikowania prac o charakterze teoretycznym podjęto również badania, które miały ustalić, jakie są zainteresowania czytelnicze dzieci w różnym wieku, jakie książki cieszą się największą popularnością i jaki wpływ wywierają na młodych czytelników. Badania przeprowadzone zostały przez A. Szycównę na grupie 50 dzieci różnej płci, w różnym wieku i o różnym pochodzeniu społecznym, objęły także rodziców i nauczycieli. Wyniki zreferowała Szycówna w numerze 23 i 24 „Przeglądu” w 1894 r. Do najpoczytniejszych pozycji należały Robinson Kruzoe i Pamiętnik chłopca (czyli Serce Amicisa) oraz książki Przyborowskiego. Komentując wybory dzieci i wymieniając książki dla nich niestosowne (m.in. tak zwane powieści dla panienek, tłumaczone $z$ innych języków), zaliczyła do nich badaczka również... Królową śniegu ${ }^{39}$.

Pozaredakcyjne formy upowszechniania książek dla dzieci i młodzieży na łamach „Przeglądu” miały głównie postać ogłoszeń wydawców, jednak zaledwie kilka oficyn z takiej możliwości promowania własnych publikacji korzystało. Kilkakrotnie reklamowali swoją ofertę dla różnych grup wiekowych M. Arct i Gebethner i Wolff. Natomiast nieliczne były ogłoszenia księgarni S. Bukowieckiego, T. Paprockiego czy K. Treptego. Stosunkowo najczęściej ogłaszały się redakcje czasopism dla dzieci. „Przyjaciel Dzieci” i „Wieczory Rodzinne” przypominały się zazwyczaj pod koniec roku, ale wychodzące od 1902 r. „Moje Pisemko” redagowane przez A. Szycównę i wydawane prze Arcta reklamowało się niemal bez przerwy. Zastanawia tak znikome wykorzystanie przez wydawców możliwości reklamowania się w czasopiśmie, które znacznie więcej miejsca niż inne ówczesne periodyki poświęcało promocji książek dla dzieci. Wydaje się, że przyczyna leży w liczbie i grupie odbiorców pisma. Nauczyciel czy inny wychowawca nie był postrzegany jako potencjalny nabywca książek, stąd wydawcy znacznie częściej reklamowali się w wysokonakładowych gazetach, które docierały do szerokiej i zróżnicowanej publiczności, dając większe szanse na znalezienie tam klientów.

${ }^{37}$ Problemy czytelnictwa poruszali m.in.: F. Łagowski, Czytanie domowe młodzieży, „Przegląd Pedagogiczny" 1898, nr 22, s. 389--392; Z. Morawska, O czytaniu, tamże 1900, nr 6, s. 117; M. Gerson-Dąbrowska, Czytanie a inne zajęcia dzieci, tamże 1904, nr 16, s. 181, nr 17, s. 196, nr 18, s. 208; J. Gażyńska, Mali czytelnicy, tamże 1905, nr 6, s. 62-64, nr 7, s. 79.

38 I. Moszczeńska, Nie dla panien, „Przegląd Pedagogiczny” 1897, nr 5, s. 73-75.

39 Tamże 1894, nr 23, s. 294-297, nr 24, s. 309-312. 
Podsumowując, „Przegląd Pedagogiczny” nie był jedynym czasopismem, które na przełomie wieków XIX i XX informowało o publikacjach dla dzieci i młodzieży. Działalność informacyjną i recenzyjną w tym zakresie prowadziła większość ówczesnych periodyków kulturalnych, prowadziły ją też gazety. W przypadku niektórych tytułów, jak np. „Ateneum”, była to krytyka literacka na stosunkowo wysokim poziomie. Jednak nigdzie przekazywanie informacji o książkach dla dzieci nie było tak systematyczne i obszerne. „Przegląd” przekazywał informacje i oceny większości ukazujących się w Królestwie wydawnictw dla dzieci. Polecano książki różnych autorów i o różnej tematyce. Konsekwentnie informowano też o wydawcach. Przeważały wprawdzie publikacje Gebethnera i Wolffa oraz Arcta, ale byli to ówcześni liderzy na rynku książki dziecięcej. Dzięki pozyskaniu do współpracy wybitnych pedagogów, a jednocześnie znawców literatury dziecięcej, „Przegląd Pedagogiczny" realizował nie tylko prostą funkcję informacji wydawniczej, ale stał się też forum kształtowania nowych poglądów na rolę książki i czytania w życiu dziecka. 